ISSN 0258-7122

Bangladesh J. Agril. Res. 39(4): 579-589, December 2014

\title{
INTERCROPPING CHILI WITH SWEET GOURD AT VARYING PLANT POPULATION
}

\author{
M. S. ALOM ${ }^{1}$, M. N. ISLAM ${ }^{1}$, M. BISWAS ${ }^{2}$ \\ A. H. M. M. RAHMAN TALUKDAR ${ }^{3}$, AND M. A. T. MASUD ${ }^{4}$
}

\begin{abstract}
The experiment was conducted at the experiment stations of Bangladesh Agricultural Research Institute (BARI) at Joydebpur and Jamalpur during two consecutive seasons of November 2010 to June 2012 to find out the appropriate plant population of chili (var. Manikgonj local at Joydebpur and Jamalpur local at Jamalpur ) for intercropping with sweet gourd (var. BARI Sweet gourd 2) for higher productivity and economic return. The treatments were : $\mathrm{T}_{1}=$ Sole sweet gourd $(2.0 \mathrm{~m} \mathrm{x} 2.0 \mathrm{~m}), \mathrm{T}_{2}=$ Sole chili $(50 \mathrm{~cm} \mathrm{x} 40 \mathrm{~cm}), \mathrm{T}_{3}=$ Sweet gourd $(100 \%)$ + chili $(100 \%), \mathrm{T}_{4}=$ Sweet gourd $(100 \%)+$ chili $(60 \%), \mathrm{T}_{5}=$ Sweet gourd $(100 \%)+$ chili $(50 \%)$ and $\mathrm{T}_{6}=$ Sweet gourd $(100 \%)+$ Chili $(40 \%)$. Averaged over the years, fruit yield of sweet gourd was reduced significantly when intercropping with more than $50 \%$ chili. Intercropping sweet gourd with chili combination $(100 \%)+$ chili $(40 \%)$ gave the highest sweet gourd equivalent yield (35.74 t/ha and 17.95 t/ha), gross return (Tk. 357400/ha and Tk. 179500/ha), gross margin (Tk. 274346/ha and Tk.124600/ha) and benefit cost ratio (4.30 and 3.27), respectively at Joydebpur and Jamalpur. The maximum land equivalent ratio (1.52 at Joydebpur and 1.56 at Jamalpur) was also obtained from sweet gourd $(100 \%)+$ chili $(40 \%)$ intercropping system. The results revealed that $40 \%$ chili population (20,000/ha) might be optimum for intercropping with sweet gourd $(100 \%)$ for higher productivity and economic return.
\end{abstract}

Keywords: Sweet gourd, Chili, Intercropping systems.

\section{Introduction}

Intercropping is a traditional practice in Bangladesh. It increases total productivity per unit area through maximum utilization of land, labour and growth resources (Ahmed et al., 2006). Greater productivity in intercropping system is commonly achieved by minimizing inter- specific competition and maximizing complementary use of growth resources (Islam, 2002). Usually plants differing in growth duration, height, rooting systems and nutrient requirements are considered to grow together in intercropping systems (Reddy and Willey, 1981). The important determinants in intercropping systems are the

${ }^{1}$ Principal Scientific Officer, Agronomy Division, Bangladesh Agricultural Research Institute (BARI), Gazipur, ${ }^{2}$ Associate Professor, Dept. of Agronomy and Haor Agriculture, SAU, Sylhet, ${ }^{3}$ Scientific Officer, Regional Agricultural Research Station, BARI, Jamalpur, ${ }^{4}$ Principal Scientific Officer, Horticulture Research Centre, BARI, Gazipur, Bangladesh. 
judicious choice of compatible crops with minimum inter-specific competition (Santalla et al., 2001). Sweet gourd is a good source of vitamin and also used as vegetable. Chili is being grown in Bangladesh as the most important spice crop. Due to decreasing cultivable land, some farmer of south-west parts of Bangladesh have been practicing sweet gourd chili intercropping system instead of sole cropping. But the farmers do not follow proper ratio of component crops especially for chili. Moreover, little information is available for planting geometry of component crops. Hence, this experiment was undertaken to find out the optimum plant population of chili for intercropping with sweet gourd for higher productivity and return.

\section{Materials and Method}

A field experiment was conducted at the experiment stations of BARI at Joydebpur ( AEZ 28) and Jamalpur ( AEZ 9) during the period from November 2010 to June, 2011 and November 2011 to June, 2012. Soil samples were collected form experimental field form a depth of $0-20 \mathrm{~cm}$ prior to application of fertilizers. Results of soil analysis are presented in Table 1.The crops received total rainfall of 327 and $310 \mathrm{~mm}$ at Joydebpur and 280 and $300 \mathrm{~mm}$ at Jamalpur during crop growing period in 2010-2011 and 2011-2012, respectively. The monthly mean maximum and minimum in temperature were $30.0^{\circ} \mathrm{C}$ and $17.9^{\circ} \mathrm{C}$, respectively during $2010-2011$ while $29.1^{\circ} \mathrm{C}$ and $17.7^{\circ} \mathrm{C}$, respectively in $2011-$ 2012 in Joydebpur. On the other hand, the monthly mean maximum and minimum temperature were $28.5^{\circ} \mathrm{C}$ and $16.8^{\circ} \mathrm{C}$ respectively during $2010-2011$ while $27.9^{\circ} \mathrm{C}$ and $15.9^{\circ} \mathrm{C}$, respectively during $2011-2012$ in Jamalpur. The treatments were: $\mathrm{T}_{1}=$ Sole sweet gourd $(2.0 \mathrm{~m} \times 2.0 \mathrm{~m}), \mathrm{T}_{2}=$ Sole chili $(50 \mathrm{~cm} \times 40$ $\mathrm{cm}), \mathrm{T}_{3}=$ Sweet gourd $(100 \%)+$ chili $(100 \%), \mathrm{T}_{4}=$ Sweet gourd $(100 \%)+$ chili $(60 \%), \mathrm{T}_{5}=$ Sweet gourd $(100 \%)+\operatorname{chili}(50 \%)$ and $\mathrm{T}_{6}=$ Sweet gourd $(100 \%)+$ chili (40\%). The sweet gourd population was 2500 for $100 \%$ whereas chili were $50000,30000,25000$ and 20000/ha for $100,60,50$ and $40 \%$, respectively. The experiment was laid out in randomized complete block design with there replications. The unit plot size was $4.0 \mathrm{~m} \mathrm{x} 4.0 \mathrm{~m}$. Fertilizer was applied at the rate of 120-80-120-20-4 kg /ha NPKSZn for sole chili through urea, triple super phosphate, muriate of potash, gypsum and zinc sulphate, respectively. In sole sweet gourd and intercrop, fertilizers were applied at the rate of 80-36-100-24-2$2 \mathrm{~kg} / \mathrm{ha}$ NPKSZnB through urea, triple super phosphate, muriate of potash, gypsum, zinc sulphate and boric acid, respectively.Cowdung @ 10 t/ha was applied as a blanket dose during final land preparation. Fifty per cent of nitrogen and all other fertilizers for sole chili were applied at the time of final land preparation and rest amount of nitrogen was applied at 25, 50 and 70 days after planting (DAP). On the other hand, full amount of all fertilizers except nitrogen were applied in pit 7 days prior to seed sowing for sole sweet gourd and intercrop. In sweet gourd, nitrogen was applied as ring method at 30 and 50 days 
after planting followed by irrigation. At Jodebpur, one seedling of sweet gourd (var: BARI Mistikumra 2) was planted in each pit and 30 days old seedling of chili ( Manikgonj local) were planted in the field on 23 November, 2010 and 2011. At Jamalpur, 15 days old seedling, of sweet gourd (var: BARI Misti kumra 2) and 30 days age seedling of chili (var: Jamalpur local) were planted in the field on 15 November, 2010 and 2011. Intercultural operations like watering, weeding, spraying of insecticides and fungicides were done as and when required. Fruit yield was calculated for sweet gourd and chili in ton per hectare considering the whole plot as harvest area. Ten plants of chili from each plot were selected randomly to collect data on yield components. Collected data were analyzed statistically with the help of MSTATC programme and mean separation was done as per Least Significant Difference (LSD) test at 5\% level of significance. Benefit cost analysis was performed considering the prevailing price of sweet gourd and green chili at the harvesting period in the local market (Reddy and Reddi, 1992). Sweet gourd equivalent yield (SGEY) was also calculated following the formula of Bandypadhyay (1984). Land equivalent ratio (LER) was calculated following the formula of Shaner et al. (1982).

Table 1. Physical and chemical properties of experimental soils of two locations.

\begin{tabular}{c|c|c|c|c|c|c|c|c}
\hline Locations & Series & $\begin{array}{c}\text { Soil } \\
\text { texture }\end{array}$ & $\mathrm{pH}$ & $\begin{array}{c}\mathrm{OM} \\
(\%)\end{array}$ & $\begin{array}{c}\text { Total } \\
\mathrm{N}(\%)\end{array}$ & $\begin{array}{c}\text { Available } \\
\mathrm{P}(\mu \mathrm{g} \text { ml })\end{array}$ & $\begin{array}{c}\text { Exchangea } \\
\text { ble K }(\mathrm{meq} \\
100 \mathrm{~g} \text { soil })\end{array}$ & $\begin{array}{c}\text { Availa- } \\
\text { ble } \mathrm{S}\end{array}$ \\
\hline Joydebpur $)$ & Chhiata & $\begin{array}{c}\text { Silty clay } \\
\text { loam }\end{array}$ & 6.1 & 0.88 & 0.053 & 10 & 0.10 & 12 \\
Jamalpur & Sonatola & Silty loam & 5.9 & 1.03 & 0.07 & 15 & 0.25 & 15 \\
$\begin{array}{c}\text { Critical } \\
\text { levels }\end{array}$ & - & - & - & - & - & 14 & 0.20 & 14 \\
\hline
\end{tabular}

\section{Results and Discussion}

Results obtained for the two years were almost similar and therefore pooled analysis was done.

\section{Yield and yield component of Chili}

Number of fruitts/ plant, fruit weight /plant and fruit yield/ha of chili were significantly affected by the sweet gourd + chili intercropping systems except plant population $/ \mathrm{m}^{2}$ in both the locations (Table 2). The highest number of fruit/plant was obtained from $\mathrm{T}_{6}$ treatment (227.29 at Joydbpur and 205.60 at Jamalpur) which was at par with $\mathrm{T}_{5}$ (208.29) at Joydebpur but significantly differed at Jamalpur. The lowest number of fruit/plant was obtained from $\mathrm{T}_{3}$ treatment (172.57 at Joydebpur and 98.25 at Jamalpur) followed by $\mathrm{T}_{2}(184.17$ at Joydebpur and 106.45 at Jalmalpur) treatment. The maximum fruit weight/plant 
was obtained from $\mathrm{T}_{6}$ treatment (364.00 $\mathrm{g}$ at Joydebpur and 294.20 at Jamalpur) and the lowest from $\mathrm{T}_{3}$ (216.03 at Joydebpur and 179.35 at Jamalpur) treatment. Yield of chili varied from 6.16 to $9.68 \mathrm{t} / \mathrm{ha}$ at Joydebpur and 2.46 to $4.30 \mathrm{t} / \mathrm{ha}$ at Jamalpur due to execution of different treatments. The differences in yield between two locations might be attributed to the difference in climatic factors. Significantly the highest fruit yield $(9.68 \mathrm{t} / \mathrm{ha}$ at Joydebpur and $4.30 \mathrm{t} / \mathrm{ha}$ at Jamalpur) of chili was observed in $\mathrm{T}_{2}$ treatment (Sole chili) and the lowest from $\mathrm{T}_{6}(6.16 \mathrm{t} / \mathrm{ha}$ at Joydebpur and $2.46 \mathrm{t} / \mathrm{ha}$ at Jamalpur) treatment. Fruit yield of chili was higher in sole plot $\left(\mathrm{T}_{2}\right)$ in both the locations might be due to higher plant population. Quayyum and Maniruzzaman (1995), Islam et al. (2006) and Santalla et al. (2001) also reported that seed yield was higher in monoculture as compared to their corresponding intercropped yield. Variation in fruit yield/ha of chili might be influenced by the plant population in the intercropping systems. Fruit yield increased with the increase of plant population.

\section{Yield and yield component of Sweet gourd}

Number of fruit/plant, fruit weight/plant and fruit yield/ha of sweet gourd were significantly affected by the treatments in both the locations except plant population/ha (Table 3). The plant population of sweet gourd remain same per plot $(2500 /$ ha) with spacing $(2 \mathrm{~m} \times 2 \mathrm{~m})$. The highest number of fruit/plant (5.88 at Joydebpur) was obtained from $\mathrm{T}_{1}$ (Sole sweet gourd) treatment but at Jamalpur, treatment $\mathrm{T}_{1}$ and $\mathrm{T}_{6}$ were identical. The lowest number of fruit/plant was found in $\mathrm{T}_{4}$ (4.09) followed by $\mathrm{T}_{3}$ (4.17) at Joydebpur whereas lower fruit/plant in $\mathrm{T}_{3}$ at Jamalpur. Single fruit weight did not differed significantly but some intercropping showed higher fruit weight in both the locations. The highest fruit yield $(25.36 \mathrm{t} / \mathrm{ha})$ was obtained from $\mathrm{T}_{1}$ treatment and it was statistically at par with $\mathrm{T}_{6}(23.42 \mathrm{t} / \mathrm{ha})$ treatment at Joydebpur. While $\mathrm{T}_{1}$ treatment showed higher fruit yield but at par with $T_{5}$ and $T_{6}$ treatments at Jamalpur. The lowest fruit yield was observed in $T_{3}$ treatment in both the locations (17.52 t/ha at Joydebpur and $10.66 \mathrm{t} / \mathrm{ha}$ at Jamalpur). Fruit yield of sweet gourd at Jamalpur was lower possibly due to the low temperature in the month of December (max. $24^{\circ} \mathrm{C}$ and min. $12^{\circ} \mathrm{C}$ ) and January $\left(\max .20^{\circ} \mathrm{C}\right.$ and $\min .8^{\circ} \mathrm{C}$ ) immediately after planting of the crops. The temperature in the month of December (max. $26^{\circ} \mathrm{C}$ and min. $14^{\circ}$ C) and January (max. $22^{\circ} \mathrm{C}$ and min. $9^{\circ} \mathrm{C}$ ) in Joydebpur after planting of sweet gourd seedling. Low temperature affected seriously the vegetative growth of the seedlings which in turn drastically reduced the fruit yield of sweet gourd. Among the intercropped treatments, $\mathrm{T}_{6}$ (Sweet gourd $100 \%$ + chili $40 \%$ ) treatment produced higher fruit yield of sweet gourd might be due to lower plant population of chili and less competition of different growth resources. 
INTERCROPPING CHILI WITH SWEET GOURD AT VARYING PLANT POPULATION 583

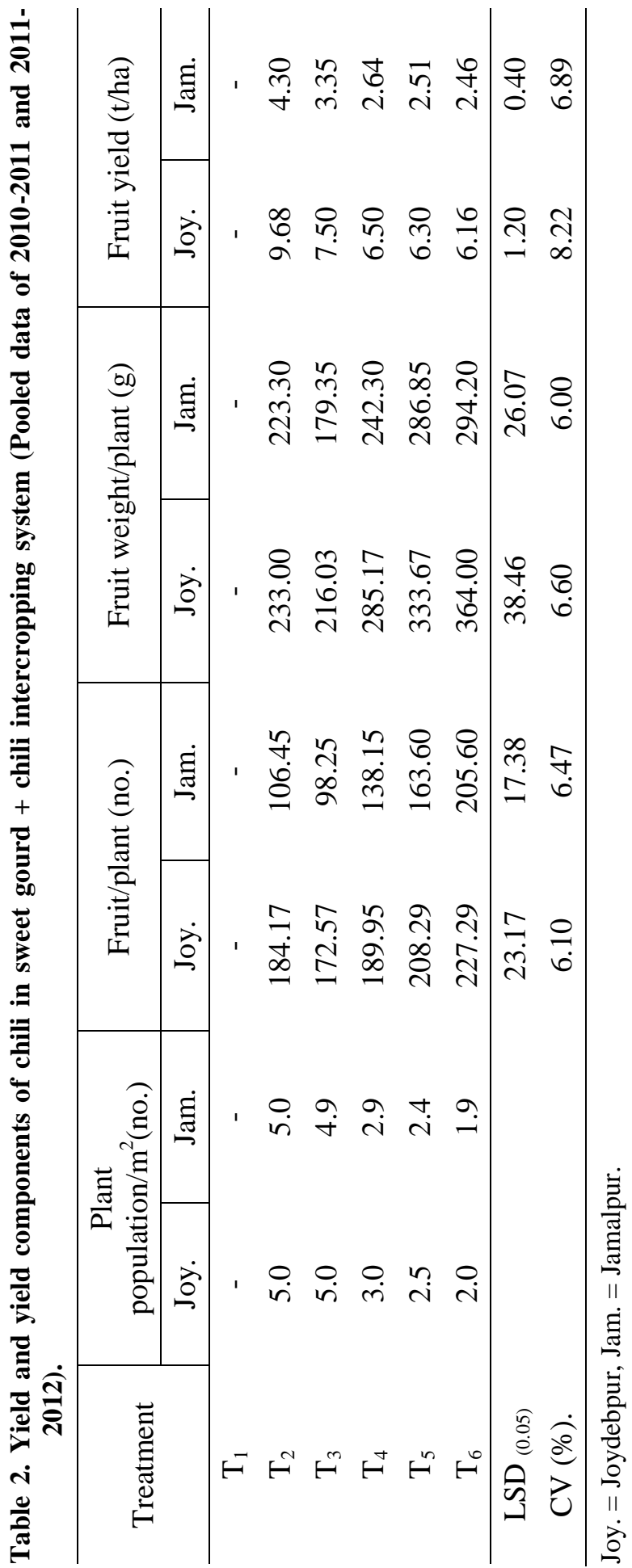




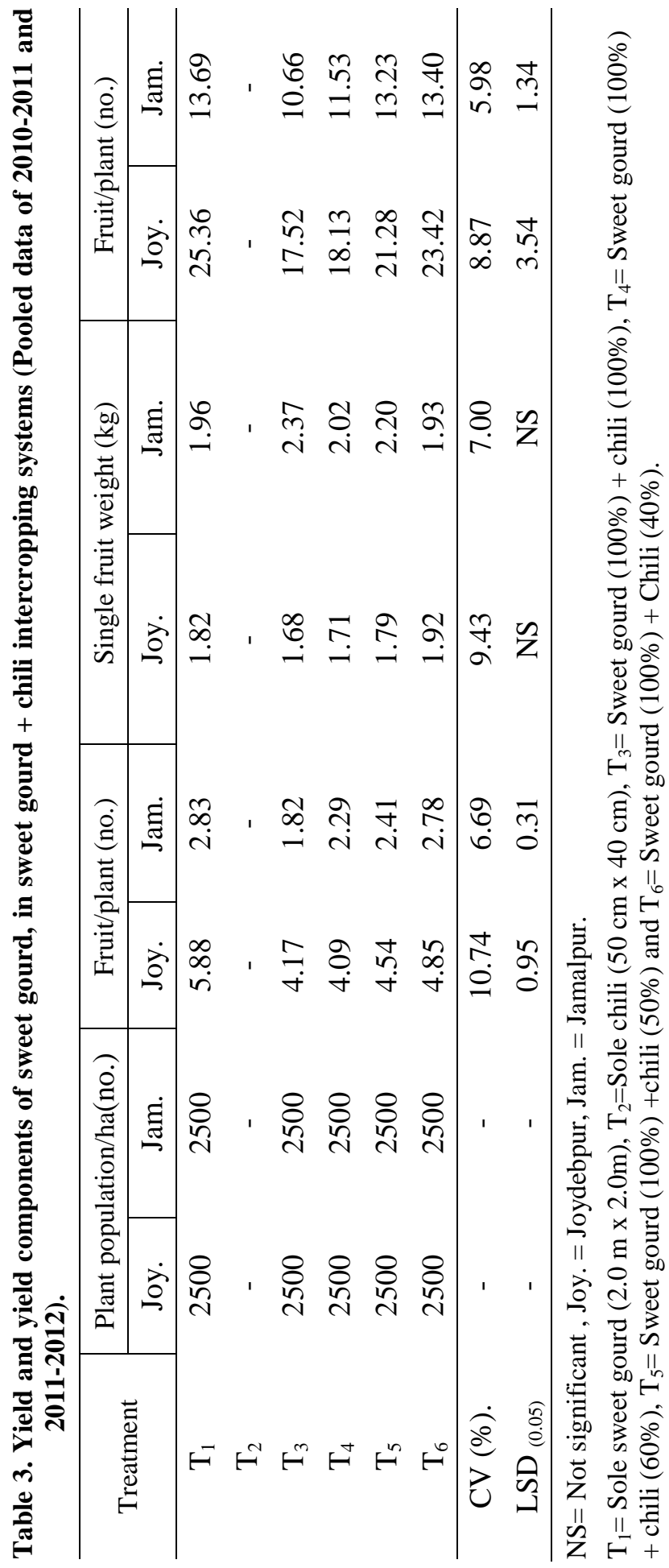




\section{Relative yield}

Sweet gourd relative yield was slightly different and ranged from 0.69 to 0.93 at Joydebpur and 0.78 to 0.98 at Jamalpur among the intercropping situations due to equal population of sweet gourd in all the intercropping plots. The yield of sweet gourd in intercropped situation was reduced by 7 to $31 \%$ at Joydebpur and 2 to $22 \%$ at Jamalpur (Table 4). Chili relative yield varied from 0.59 to 0.74 at Joydebpur and 0.58 to 0.76 at Jamalpur among the intercropping treatments due to different plant population of chili. Maximum yield (41\%) rreduction was noticed in $\mathrm{T}_{6}$ treatment and minimum in $\mathrm{T}_{3}$ treatment $(36 \%)$. The yield reduction varied from 26 to $41 \%$ at Joydebpur and 24 to $42 \%$ at Jamalpur in intercropped situation (Table 4).

\section{Land equivalent ratio}

The land equivalent ratio (LER) value is more than one (1.00) indicates yield advantage of intercropping. LER values in the intercrops range from 1.39 to 1.52 at Joydebpur and 1.46 to 1.56 at Jamalpur which indicated $39-52 \%$ and $46-56 \%$ yield advantage at Joydebpur and Jamalpur, respectively due to intercropping (Table 4). The highest LER value (1.52 at Joydebpur and 1.56 at Jamalpur) was noted in $\mathrm{T}_{6}$ (sweet gourd $100 \%+$ chili $40 \%$ ) treatment possible due to maximum complementary use of different growth resources in sweet gourd + chili intercropping systems. LER value of 1.52 and 1.56 indicating productivity of intercropping 52 and 56\% more land by growing sweet gourd and chili as intercropped at Joydebpur and Jamalpur, respectively. It also express that by intercropping sweet gourd with chili, a farmer can produce 23.42 ton sweet gourd and 6.16 ton chili at Joydebpur and 13.40 ton sweet gourd and 2.46 ton chili at Jamalpur from one hectare of land instead of growing sole crop. The results are in agreement with the findings of Karim et al. (1990) and Quayyum and Maniruzzaman (1995).

\section{Sweet gourd equivalent yield (SGEY)}

The sweet gourd equivalent yield was influenced in response to their different planting systems (Table 4). The maximum sweet gourd equivalent yield (35.74 $\mathrm{t} / \mathrm{ha}$ at Joydebpur and $17.95 \mathrm{t} / \mathrm{ha}$ at Jamalpur) was obtained from $\mathrm{T}_{6}$ treatment followed by $\mathrm{T}_{5}(33.89 \mathrm{t} / \mathrm{ha}$ at Joydebpur and $17.87 \mathrm{t} / \mathrm{ha}$ at Jamalpur) treatment. It was noted that higher sweet gourd equivalent yield was recorded in the intercropped treatments than the both sole crop. SGEY in treatment $\mathrm{T}_{6}$ (sweet gourd $100 \%$ + chili $40 \%$ ) was $40.93 \%$ higher at Joydebpur and $31.12 \%$ at Jamalpur over the sole sweet gourd. Similar results were recorded by Pandita et al, (1998), Sarker (1999) and Patra et al. (2000) in different intercropping systems. 


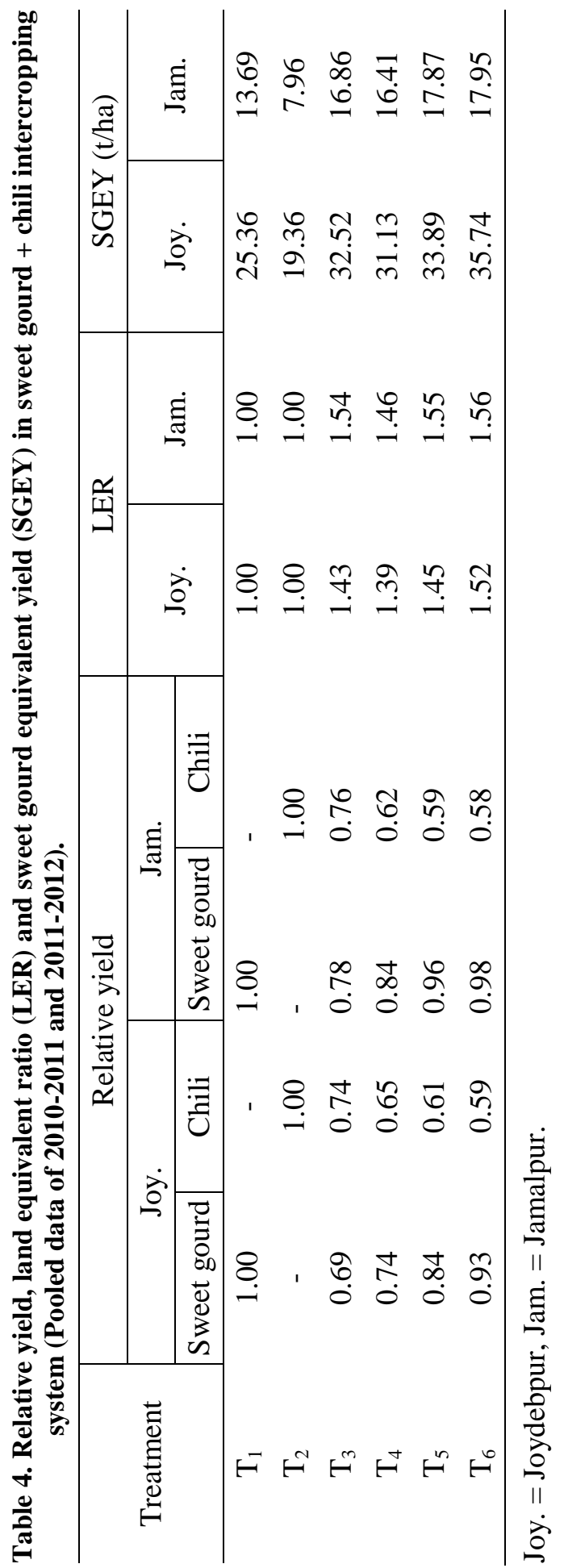


INTERCROPPING CHILI WITH SWEET GOURD AT VARYING PLANT POPULATION 587

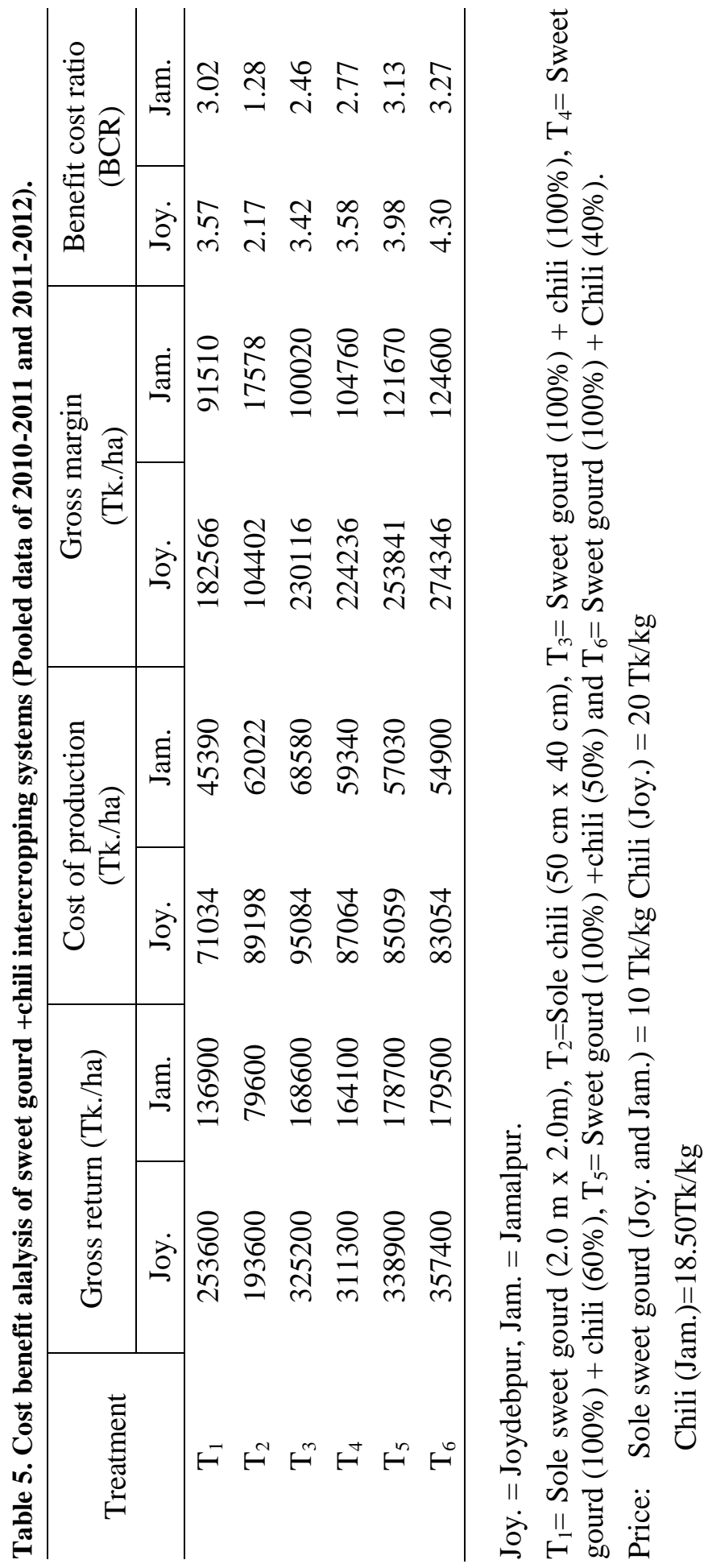




\section{Cost benefit analysis}

The highest gross return (Tk. 357400/ha at Joydebpur and Tk. 179500/ha at Jamalpur), gross margin (Tk 274346/ha at Joydebpur and Tk. 124600 at Jamalpur) and benefit cost ratio (4.30 at Joydebpur and 3.27 at Jamalpur) were found in $\mathrm{T}_{6}$ treatment (sweet gourd $100 \%+$ chili $40 \%$ ). Sole crop of chili gave the lowest gross return (Tk. 193600/ha at Joydebpur and Tk. 7900/ha at Jamalpur), gross margin (Tk 104402/ha at Joydebpur and Tk. 17578/ha at Jamalpur), and benefit cost ratio (2.17 at Joydebpur and 1.28 at Jamalpur)( Table 5). Cost of cultivation was increased in sole chili and in different intercrops probably due to involvement of more labour for transplanting of chili seedling. Thus the highest cost (Tk. 95084/ha at Joydebpur and Tk.68580/ha at Jamalpur) was involved in $\mathrm{T}_{3}$ treatment (sweet gourd $100 \%+$ chili 100\%) and the lowest (TK. 71034/ha at Joydebpur and Tk.45390/ha at Jamalpur) in $\mathrm{T}_{1}$ (sole sweet gourd) treatment.

\section{Conclusion}

The results of two locations reveled that the optimum plant population (20000 /ha) of chili might be $40 \%$ for intercropping with sweet gourd (100\%) for obtaining higher productivity and economic return.

\section{References}

Ahmed, F., M.A. Rahman,M.A.H.S. Jahan, M. Ahmed and M.A. Khayer. 2006. Effect of different planting systems in maize /spinach-red amaranth intercropping. Bangladesh J. Agric and Environ. 2(2):69-79

Bandyopadhyay, S.K. 1984. Nitrogen and water relations in grain sorghum- legume intercropping systems. Ph.D Dissertation, Indian Agricultural Research Institute (IARI), New Delhi-12. India.

Islam, M. N. 2002. Competitive interference and productivity in maize-bushbean intercropping system. A Ph D. Dissertation, Dept. of Agronomy, Bangabandhu Sheikh Mujibur Rahman Agricultural University, Gazipur

Islam, M.N., M.M.Haque and A.Hamid. 2006. Planting arrangement and population density effects on the physiological attributes and productivity of maize- bush bean intercropping system. Bangladesh J. Agril. Res. 31 (3), 353-364.

Karim, M.A.,S.S. Zaman, and M. A. Quayyum. 1990. Study on groundnut rows grown in association with normal and paired row of maize. Bangladesh J. Agril. Sci. 17(1) : 99-102.

Pandita, A.K., M. H. Shah and A.S. Bali. 1998. Row ratio in maize (Zea msys L.) legume intercropping in temperate valley condition. Indian J.agric. Sci. 68(10): 633-5.

Petra, B.C., B. K. Mandal and A.L. Padhi. 2000. Production potential of winter maize (Zea mays L .) based intercropping systems. Indian J. agric. Sci. 70 (4): 203-206. 
Quayyum, M.A. and A.F.M.Mairuzzaman. 1995. Effect of maize (Zea mays L.) and rice (Oryza sative) with blackgram (Phaseolus mungo ). Indian J. Agron, 40 (1): 20-25.

Reddy, M. S. and R. W. Willey. 1981. Growth and resource use studies in an intercrop of pearl millet/groundnut. Field Crops Res. 4:13-24.

Reedy, T.Y. and G.H. S. Reddi. 1992. Principles of Agronomy, Kalyanim Publishers. New Delhi-110002. India. P. 423.

Santalla, M., Rodino, A.P., Casquero, P.A. and De Ron, A. M. 2001. Interactions of bush bean intercropped with field and sweet maize. European J. Agron. 15: 185-196.

Sarker, R.A. 1999. Relative performance of intercropping of cowpea and wheat in association with maize. Bangladesh J. Agril. Res. 24: 443-449.

Shaner, W.W., P.E. Philipp and W.R. Schmel. 1982. Farming systems research and development, west view press. USA. Pp. 323-324. 